\title{
FRAGMENTED BIODIVERSITY: FERNS AND LYCOPHYTES FROM FOREST FRAGMENTS IN JUIZ DE FORA, MINAS GERAIS, BRAZIL
}

\author{
Lucas Vieira Lima ${ }^{1,4}$ \\ Vinícius Antonio de Oliveira Dittrich² \\ Filipe Soares de Souza ${ }^{1}$ \\ Cassiano Ribeiro da Fonseca ${ }^{3}$ \\ Alexandre Salino ${ }^{1}$
}

\section{ABSTRACT}

The Atlantic Forest is one of the most threatened formations in the world. In this context, the urbanization process stands out as one of the major factors causing environmental degradation, mainly due to the loss of native vegetation and habitat destruction. In order to fill this gap, we carried out the inventory of ferns and lycophytes in the forest remnants of the municipality of Juiz de Fora. We analyzed more than 1,353 samplings recorded throughout approximately 150 years, as result we recorded a total of 174 species distributed in 73 genera and 26 families. The most representative families were Pteridaceae with 32 species, followed by Polypodiaceae with 26 and Thelypteridaceae with 20 . In addition, we present the historical data on the sampling of ferns and lycophytes, as well as the history of the fragmentation process of the Atlantic Forest remnants in the municipality. Juiz de Fora becomes an interesting model for broader floristic studies, generating subsequent subsidies for ${ }^{1}$ Departamento de Botânica, Instituto de Ciências Biológicas, Universidade Federal de Minas Gerais. Av. Presidente Antônio Carlos, 6627-Pampulha, CEP 31270-901, Belo Horizonte, MG, Brazil.

${ }^{2}$ Departamento de Botânica, Instituto de Ciências Biológicas, Universidade Federal de Juiz de Fora, Rua José Lourenço Kelmer, s/n - Campus Universitário, São Pedro, CEP 36036-900, Juiz de Fora, MG, Brazil.

${ }^{3}$ Núcleo de Biologia, Instituto Federal de Educação, Ciência e Tecnologia do Sudeste de Minas Gerais, Campus Juiz de Fora, Rua Bernardo Mascarenhas, 1283-Bairro Fábrica, CEP: 36080-001, Juiz de Fora, MG, Brasil.

${ }^{4}$ Corresponding Author: lucaslima1618@gmail.com 
conservation actions and preservation of the natural patrimony.

Key words: Atlantic forest, pteridophytes, Semideciduous Seasonal Forest,

\section{RESUMO}

A Floresta Atlântica é um dos domínios mais ameaçados do planeta. Neste contexto, o processo de urbanização configura-se como um dos maiores fatores causadores da degradação ambiental, fundamentalmente pela extinção da vegetação nativa e destruição de habitats. Visando contribuir para o preenchimento desta lacuna, foi realizado o inventário das samambaias e licófitas nos remanescentes florestais do município de Juiz de Fora. No total, foram analisados mais de 1353 registros de coletas realizadas no intervalo de aproximadamente 150 anos. Foram registradas 174 espécies, distribuídas em 73 gêneros e 26 famílias. As famílias mais representativas foram Pteridaceae com 32 espécies, seguida de Polypodiaceae com 26 e Thelypteridaceae com 20. Adicionalmente, são apresentados dados históricos de coletas de samambaias e licófitas, bem como o histórico da fragmentação dos remanescentes de Floresta Atlântica no município. Deste modo Juiz de Fora torna-se um interessante modelo para estudos florísticos mais amplos, gerando assim posteriores subsídios para ações de conservação e preservação do patrimônio natural da humanidade.

Palavras-chave: Floresta Atlântica, Pteridófitas, Floresta Estacional Semidecidual 


\section{INTRODUCTION}

Ferns and lycophytes are two distinct lineages of seedless vascular plants, sharing a life cycle in which the gametophytic phase is independent from the sporophytic one (Page, 1979; PPG I, 2016). In a recent review of the classification of ferns and lycophytes (PPG I, 2016), it has been estimated that there are 11,916 species. One of the main centers of diversity and endemism is the neotropical region (Moran 2008), with much of the species richness and endemism associated with the mountains of southeastern Brazil, Mexico, and the Andes (Tryon, 1972; Moran 2008).

Almeida \& Salino (2016) demonstrated that, despite the current favorable scenario for the use of new molecular and computational techniques in systematic and biogeography studies, there is still a large gap in the knowledge about the diversity of groups of ferns and lycophytes. Among the factors related to the lack of knowledge about the diversity and patterns of geographic distribution of ferns and lycophytes, the main ones are the degradation, fragmentation and destruction of habitats in megadiverse neotropical countries such as Brazil (Almeida \& Salino, 2016, Cincotta et al., 2000; Meyer et al., 2000).

The Atlantic Forest domain is an important set of ecosystems with high levels of endemism and richness (Myers et al., 2000, Stehmann et al., 2009), considered as one of the 34 global biodiversity hotspots (Mittermeier et al., 2004). Due to a long history of exploitation and degradation, currently only $7-8 \%$ of the original coverage remains (Galindo-Leal \& Câmara, 2005). More recent studies using remote sensing methodologies with a resolution of $5 \mathrm{~km}^{2}$ demonstrated the recovery of vegetation cover in the Atlantic Forest, reaching $28 \%$ of the original coverage (Rezende et al., 2018). However, these remaining areas are constituted by mosaics of small and biologically impoverished fragments, on average smaller than 100 ha, whose restoration could take hundreds of years (Liebsch et al., 2008, Ribeiro et al., 2009, 2011).

The Seasonal Semideciduous Forest (SSF) is today restricted to a mosaic of forest fragments at different stages of regeneration (Whitmore, 1978, Ferreira Júnior et al., 2007), contrasting with its wide past distribution. According to Stehmann et al., (2009), this formation is the second most important in terms of plant richness and endemism in the Atlantic Forest domain. For fern and lycophyte species, 48\% (406 spp.) of the total recorded for the Atlantic Forest (840 spp.) occur at SSF, of which 
about 33\% (89) of them are endemic to the formation (Salino \& Almeida, 2009a).

The municipality of Juiz de Fora, located in the southeastern portion of the state of Minas Gerais, is predominantly under the domain of the Semideciduous Seasonal Forest (Lima \& Dittrich, 2016; PMJF, 2017). The native forest cover was almost completely destroyed, initially by opening up areas for agricultural activities, with emphasis on the coffee culture, later transformed into pasture areas, mainly of molasses grass (Melinis minutiflora P. Beauv.) and more recently palisade or signal grass (Urochloa spp.). The few remaining forest fragments are represented mainly by secondary formations in different succession stages (Almeida, 1996).

In addition, the constant anthropic pressures in response to the increased demands of the human population constitute an imminent threat to the maintenance of biodiversity (Almeida \& Salino, 2016). In the last 20 years, the population of Juiz de Fora has grown by around $24 \%$, reaching approximately 560 thousand inhabitants (IBGE 2016). The municipality currently has about 28 thousand hectares of native vegetation cover, which represent approximately $20 \%$ of its territory (Scolforo \& Carvalho, 2006, Fonseca \& Carvalho, 2012). However, only 4\% of these forested areas are under protection in conservation units (Fonseca \& Carvalho, 2012, PMJF, 2017).

The long history of exploitation and degradation to which the municipality's vegetation is subjected and its importance in the representativeness of the Atlantic Forest fragments make it essential to carry out inventories of the flora of this area. In this context, the present study had as its main objective carrying out the inventory of ferns and lycophytes of the forest fragments in Juiz de Fora.

\section{MATERIALS AND METHODS}

We reviewed all specimens of ferns and lycophytes from the studied area deposited in the BHCB and CESJ and herbaria (acronyms according to Thiers, 2020). In addition, we consulted and reviewed the identifications of specimens with images available in the following virtual herbaria: INCT- Herbário Virtual da Flora e dos Fungos (INCT- Virtual Herbarium of Flora and Fungi 2018), Jabot - Banco de dados da Flora Brasileira (JBRJ, 2017), and Reflora - Virtual Herbarium (Reflora, 2017). In a total we reviewed 1353 records of ferns and lycophytes from all forest remnants of Juiz de Fora. 
The municipality of Juiz de Fora is located in the southeast of the state of Minas Gerais, between the approximate geographical coordinates of $21^{\circ} 31^{\prime} 16^{\prime \prime}$ and $21^{\circ} 59^{\prime} 59^{\prime \prime} \mathrm{S}$ and $43^{\circ} 08^{\prime} 50^{\prime \prime}$ and $43^{\circ} 41^{\prime} 10^{\prime \prime} \mathrm{W}$. The regional climate can be characterized as Köppen type Cwa (mesothermal, with hot and rainy summers). The average annual precipitation, measured between the years 1999 and 2011, is $1627.8 \mathrm{~mm}$ and the average annual temperature is around $19.3^{\circ} \mathrm{C}$, for the same period. The altitude varies from 467 to $1104 \mathrm{~m}$ and the relief is diverse, with concaveconvex hills and valleys (Anuário Estatístico de Juiz de Fora, 2012). The municipality has remaining areas of Atlantic Forest, permeated by the city. Around $24 \%(9,662$ ha) of the urban area of the municipality of Juiz de Fora is covered by forests, distributed in 1,122 fragments. Consequently, the average size of these fragments is 8.61 ha (Barros 2015). Most of these fragments have different sizes, are at different stages of regeneration and still suffer constant impact from anthropic action.

We used ArcGIS ver. 10 (ESRI 2011) to build a map showing the forest areas of Juiz de Fora (Figure 2). We adopted PPG I (2016) as the classification system, and follow the definitions of Lellinger (2002) and Zuquim et al., (2008) to categorized the species' preferential substrate in: terrestrial, rupicolous, corticicolous, hemicorticicolous, amphibians, and aquatic.

\section{RESULTS}

\section{Sampling history}

The first samplings of ferns and lycophytes in the municipality of Juiz de Fora date from the second half of the 19th century. Elaphoglossum nigrescens was the first species to be sampled. Collected in February 1862, it was deposited at Herbário Capanema in Manaus (Amazonas State). Currently the specimen is stored in the herbarium of the Botanical Garden of Rio de Janeiro (RB) (RB00687659), and the voucher has an original label dated 1862, in addition to another label transcribed with the spelling of Alex Curt Brade (1881-1971), with the date changed to 1863.

At the beginning of the 20th century, other samplings were made by the Carl August Wilhelm Schwacke (1848-1904). The specimens came from one of Schwacke's expeditions to the state of Minas Gerais, passing through Juiz de Fora between June and July of 1902 . The locations sampled by Schwacke in Juiz de Fora were Poço d'Anta and Morro do Imperador, where 14 species were sampled, most of which are stored at the RB herbarium. Subsequently, the ferns and lycophytes of Juiz 
de Fora was explored by Brade in two sampling expeditions, in 1934 and 1937 respectively, in which another 14 species were recorded for the municipality.

From the first sampling to the first half of the 20th century, although the municipality of Juiz de Fora had great importance in the national context for coffee production and its industries, the knowledge local flora remained incipient. The second half of the 20th century was marked by a significant increase in samplings, driven by the founding of the Leopoldo Krieger Herbarium (CESJ) in 1940, as an initiative of the priests Leopoldo Krieger (1919-2008) and Luiz Roth, by the time students of Theology (Salimena \& Menini-Neto, 2008).

The first samplings by Krieger and Roth in Juiz de Fora date from the years 1942, 1948, and 1949. These are single samplings of which only 28 specimens were incorporated into the newly founded herbarium. In 1969 Krieger was hired as a professor at the Universidade Federal de Juiz de Fora (Salimena \& Menini-Neto, 2008). From this date, a significant volume of samplings was recorded for the municipality, done by the priest and his students until the end of the 1980s. Of the 1,353 sampling records for the municipality, approximately $672(49 \%)$ were collected by Krieger, who was the first sampler in more than $90 \%$ of the cases, between 19691989. From 1990 to the present, with the Biology course at Universidade Federal de Juiz de Fora already strongly consolidated, samplings started to be done by a more varied number of samplers and the number of records practically doubled.

\section{Floristic composition}

We found 175 species, distributed in 73 genera and 26 families. The richest families were Pteridaceae with 32 species and eight genera (18\% of species), Polypodiaceae with 26 species and eight genera (14\%) and Thelypteridaceae with 20 species and seven genera (11\%) (Figure 1, Table 1). The most representative genera were Adiantum, with nine species, Amauropelta, Asplenium, Microgramma, and Pteris, with seven each, Cyathea and Selaginella, with six each, Anemia, Ctenitis, Doryopteris, Pleopeltis, and Serpocaulon, with five species each. Regarding the habit, about $16 \%$ of the species are epiphytes and about $84 \%$ are terrestrial or rupicolous. In addition, naturalized species such as Deparia petersenii, Macrothelypteris torresiana, Christella dentata, and Pteris vittata were collected.

\section{DISCUSSION}

Salino \& Almeida (2009a) pointed out, among the main threats to species of 
ferns and lycophytes in the State of Minas Gerais, the decrease and degradation of habitats, due to the subsequent decline in the optimum conditions for establishment and survival. Nevertheless, Lima \& Dittrich (2016) recorded 78 species in only three remaining areas of Atlantic Forest in Juiz de Fora, which represent nearly $43 \%$ of the total registered here. This shows that few areas, even if immersed in an urban matrix with more than 500 thousand inhabitants, may house a high number of species of native flora.

The results of the present study point to a higher number of species compared to inventories carried out in other areas of the Southeast and South of Brazil in which the main phytophysionomy is composed of Seasonal Semideciduous Forest (SSF) (Table 2). Colli et al. (2004b) recorded 34 species for Seasonal Semideciduous Forest from Parque Estadual de Vassununga, São Paulo State, in an area of 1,732 ha with an altitude between 500-750m. Melo \& Salino (2002a) recorded 116 species for Parque Estadual do Rio Doce (PERD), which has a larger area with 35,970 ha. Despite the large area of forest of PERD, less fragmented than the forest formations of Juiz de Fora, the low number of species found may be related to the low altitude and limited altitudinal variation of PERD (215 to 525m). Salino \& Almeida (2009a) showed that altitudinal ranges above $700 \mathrm{~m}$ are the richest in the state of Minas Gerais. Similarly, Senna \& Kazmirczak (1997) recorded 45 species in an area of 1,031 ha of Seasonal Semideciduous Forest in Morro da Extrema, Rio Grande do Sul State. In this case, the low number of species may be associated with the maximum altitude of the area at $225 \mathrm{~m}$ (Table 2). Furthermore, the southern region of Brazil has fewer species of ferns and lycophytes than the southeastern region (Flora do Brasil 2020 Online 2020).

Melo \& Salino (2002b) recorded 102 species in an area of 880 ha of SSF at Estação Biológica de Caratinga, Minas Gerais. This area has medium altitudes, and the forest remnants are more continuous than those of Juiz de Fora (JF). It is to be expected that in inventories on a regional scale, as performed in JF, the number of species will be greater than inventories on a local scale (Mehltreter 2010). However, the lower number of species found when we observe the species/area ratio may be associated with the broad history of exploitation, degradation, and fragmentation of forest formations in Juiz de Fora.

Similarly, Figueiredo \& Salino (2005) recorded 190 species in fragmented areas in the metropolitan region of Belo Horizonte, Minas Gerais. Such areas 
comprise a mosaic of phytophysiognomies in a transition zone between Cerrado and Atlantic Forest, of which the predominant phytophysionomy is Seasonal Semideciduous Forest. This work demonstrates that, as in Juiz de Fora, such fragmented areas, although under constant threat, can be important refuges and harbor a considerable number of native species.

According to Salino \& Almeida (2009a), in their diagnosis of the ferns and lycophytes flora of the Minas Gerais State, the SSF was the forest formation with the highest number of species (429 spp. - 62.5\%), exceeding the number of species recorded for the Tropical Rain Forest (384 spp. - 56\%). The authors also correlate these factors to the relief of the state, since in Minas Gerais the domain of the Semideciduous Forest is mainly restricted to mountainous regions, where there are many deep valleys that allow the occurrence of most ferns and lycophytes.

Here 16 species for SSF listed by Salino \& Almeida (2009b) as exclusive of the Atlantic Tropical Rain Forest (Table 1). These new records may be associated with some factors related to sampling deficiency and the fluctuation of micro-habitats due to variations in the relief forms of the studied area. Examples of these species are representatives of Hymenophyllaceae, registered mainly in the Rio do Peixe region, and Danaea excurrens (Marattiaceae), found in a valley bottom. On the other hand, it is interesting to note that Pteridaceae is the richest family (33 spp., Table 1), surpassing Polypodiaceae, Dryopteridaceae and Thelypteridaceae, a pattern that traditionally occurs in SSF formations (Melo \& Salino, 2002; Salino \& Almeida, 2009).

Regarding the rates of epiphytes, the present study found $16 \%$, which seems to be close to the rates found in other SSF inventories such as Colli et al. (2007), for Reserva Estadual de Águas da Prata (15\%), Colli et al. (2004b), for Parque Estadual de Vassununga (20\%), and higher than the values found by Melo \& Salino (2002a) for Estação Biológica de Caratinga (8.5\%), Melo \& Salino (2002b) for Parque Estadual do Rio Doce (8.2\%), and Senna \& Kazmirczak (1997) for Morro da Extrema (8\%). These indexes are in accordance with the pattern found for this type of forest formation (SSF), with the regeneration stages of forest fragments, and may be associated with seasonality influencing the air humidity indexes, which is essential for the establishment of epiphytic plants (Figueiredo \& Salino 2005).

Among the native species recorded, Elaphoglossum acrocarpum (Dryopteridaceae) stands out as threatened with extinction in the vulnerable category according to Kieling-Rubio et al. (2013). However, a few species of ferns and 
lycophytes can favor themselves in anthropized environments and increase the abundance of their populations, such as Lycopodium clavatum and species of Gleicheniaceae, such as Dicranopteris flexuosa and Gleichenella pectinata. Such plants occupy anthropized and altered areas like ravines by the roadsides. In addition, naturalized species can also benefit from environmental change and be widely spread, such as Macrothelypteris torresiana, Christella dentata, Pteris vittata, and Deparia petersenii, all found in Juiz de Fora. Finally, species of Gleicheniaceae and Pteridium (Dennstaedtiaceae), like the ones record to JF, can directly influence the process of succession and regeneration of secondary forests, both delaying the process and competing directly with native species (Mehltreter 2010).

Habitat destruction has a direct impact on the diversity of most species of lycophytes and ferns and may even lead to the extinction of local populations (Salino \& Almeida 2009a, Mehltreter 2010). Through the observation of the extensive sampling history of more than 150 years, it is possible to assess that the frequency of sampling of some taxa changes. The three species of the genus Elaphoglossum (E. acrocarpon, E. nigrescens, and E. macrophyllum) recorded here were sampled only once, which may signal the imminent risk to the conservation of the local vascular flora.

Recently, a new species of Dryopteridaceae, Ctenitis christensenii R.S.Viveros \& Salino, was described for the Brazilian Atlantic Forest and is here recorded for the first time for Juiz de Fora. The species was sampled only once in the municipality by Brade in 1937. Other than that, there is no other record of this species in the region, which means there is a great chance that this species may be locally extinct, as well as some other species. On the other hand, some species have a low frequency of collection due to specific characteristics of their biology such as Ophioglossum reticulatum - which is an annual plant - and Pleopeltis minima, which in addition to the small size presents poikilohydry, which makes it difficult to be spotted during the dry season.

Regenerating forest ecosystems hold only part of the original biodiversity (Paciência 2001), which is valid for forest fragments in the municipality of Juiz de Fora, which, despite the history of devastation and the different stages of regeneration, presents a high richness of ferns and lycophytes. The loss of biodiversity of the ferns and lycophytes in the studied areas may be associated with the deterioration of the optimum conditions of the environments, such as the changes 
in humidity and shading when compared to those offered in primary forests.

The regeneration of the studied forest fragments in the municipality of Juiz de Fora attests to the high resilience of the Atlantic Forest (Pinto \& Brito 2003, Rezende et al. 2018), as exemplified by the regeneration of the Krambeck forest, which after being destroyed to form pastures, after 70 years of regeneration has shown significant recovery (Lima \& Dittrich 2016). With the conservation of these forest areas over the years (progress in the succession process), the colonization of new species of ferns and lycophytes may occur and the abundance of more demanding species in terms of shade and humidity may increase (Figueiredo \& Salino 2005). Therefore, the present results reaffirm the importance of maintaining and conserving urban forest fragments for sustaining Brazilian biodiversity in one of the biomes most affected by anthropic action.

\section{ACKNOWLEDGEMENTS}

We thank Thaís Elias Almeida for notes and comments about this manuscript. This study was financed in part by the Coordenação de Aperfeiçoamento de Pessoal de Nível Superior - Brasil (CAPES) - Finance Code 001 (88887.19244/2018-00). We also thank CNPq for the research grant and scholarship (307115/2017-8) to $A$. Salino.

\section{REFERENCES}

ALMEIDA, D. 1996. Florística e estrutura de um fragmento de Floresta Atlântica, no município de Juiz de Fora, Minas Gerais. Dissertação de Mestrado. Universidade Federal de Viçosa, Viçosa.

ALMEIDA, T.E. \& SALINO, A. 2016. State of the art and perspectives on neotropical fern and lycophyte systematics. Journal of Systematic and Evolution 54: 679-690.

ANUÁRIO ESTATÍSTICO DE JUIZ DE FORA. 2012. Juiz de Fora. Available at < http://www.cps.ufjf.br/anuarios/Anuario2012/index.html>. Access on 07 March 2020.

BARROS, K.D.A.R.T. 2015. Levantamento dos fragmentos florestais da cidade de Juiz de Fora, Minas Gerais, Brasil. Dissertação de Mestrado. Universidade Federal de Juiz de Fora, Juiz de Fora.

CINCOTTA, R.P.; WISNEWSKI, J. \& ENGELMAN, R. 2000. Human population in the 
biodiversity hotspots. Nature 404: 990-992.

COLLI, A.M.T.; SALINO, A.; FERNANDES, A.C.; RANGEL, C.M.; BARBOSA, R.A.; CORREIA, R.A. \& SILVA, W.F. 2004a Pteridófitas da Floresta Estadual de Bebedouro, Bebedouro, São Paulo, Brasil. Revista do Instituto Florestal 16: 147152.

COLLI, A.M.T.; SALINO, A.; SOUZA, A.S.; LUCCA, A.L.T. \& SILVA, R.T. 2004b. Pteridófitas do Parque Estadual da Vassununga, Santa Rita do Passa Quatro (SP), Brasil. Glebas Capetinga Leste e Capetinga Oeste. Revista do Instituto Florestal 16: 25-30.

ESRI. 2011. ArcGIS Desktop: Release 10. Redlands, CA: Environmental Systems Research Institute.

FERREIRA JÚNIOR, W.G.; SILVA, A.F.; MEIRA NETO, J.A.A.; SCHAEFER, C.E.G.R.; DIAS, A.S., IGNÁCIO, M. \& MEDEIROS, M.C.M.P. 2007. Composição florística da vegetação arbórea de um trecho de floresta estacional semidecídua em Viçosa, Minas Gerais, e espécies de maior ocorrência na região. Revista Árvore 31: 1121-1130.

FIGUEIREDO, J.B. \& SALINO, A. 2005. Pteridófitas de quatro reservas particulares do patrimônio natural ao sul da região metropolitana de Belo Horizonte, Minas Gerais, Brasil. Lundiana 6: 83-94.

FILGUEIRAS, T.S.; BROCHADO, A.L.; NOGUEIRA, P.E. \& GUALLA, G.F. 1994. Caminhamento -um método expedito para levantamentos florísticos qualitativos. Cadernos de Geociências 12: 39-43.

FLORA DO BRASIL 2020 EM CONSTRUÇÃO 2020. Jardim Botânico do Rio de Janeiro. Available at < http://floradobrasil.jbrj.gov.br/ > Access on 30 June 2020.

FONSECA, C.R. \& CARVALHO, F.A. 2012. Aspectos florísticos e fitossociológicos da comunidade arbórea de um fragmento urbano de Floresta Atlântica (Juiz de Fora, MG, Brasil). Bioscience Journal 28: 820-832.

GALINDO-LEAL, C.; JACOBSEN, T.R.; LANGHAMMER, P.F. \& OLIVIERA, S. 2005 Estado dos hotspots: a dinâmica da perda de biodiversidade. In Mata Atlântica: biodiversidade, ameaças e persperctivas (GALINDO-LEAL, C. \& CÂMARA, I.G., eds). Ed. Fundação SOS Mata Atlântica/Conservação Internacional, Belo Horizonte. Pp. 12-23. 
KIELING-RUBIO, M.A.; MATOS, F.B.; CONDACK, J.P.S.; MAURENZA, D.; PENEDO, T.S.A. \& MESSINA, T. 2013. Dryopteridaceae. In Livro vermelho da flora do Brasil (MARTINELLI, G. \& MORAES, M.A., eds), Ed. Jardim Botânico do Rio de Janeiro, Rio de Janeiro. Pp.847-849.

LELLINGER, D.B. 2002. Modern multilingual glossary for taxonomic pteridology. Pteridologia 3:1- 263.

LIEBSCH, D.; MARQUES, M.C. \& GOLDENBERG, R. 2008. How long does the Atlantic Rain Forest take to recover after a disturbance? Changes in species composition and ecological features during secondary succession. Biology Conservation 141: 1717-1725.

LIMA, L.V. \& DITTRICH, V.A.O. 2016. Licófitas e monilófitas de três áreas de remanescentes de Floresta Estacional Semidecidual no município de Juiz De Fora, Minas Gerais, Brasil. Pesquisas, Botânica 69:183-198.

MEHLTRETER, K. 2010. Fern conservation. In Fern Ecology (MEHLTRETER, K.; WALKER, L.R. \& SHARPE, J.M., eds). Ed. Cambridge University Press, Cambridge. Pp. 323-359.

MELO, L.C.N. \& SALINO, A. 2002. Pteridófitas de duas áreas de floresta da Bacia do Rio Doce no Estado de Minas Gerais, Brasil. Lundiana 3:129-139.

MELO, L.C.N. \& SALINO, A. 2007. Pteridophytes from APA Fernão Dias, Minas Gerais, Brazil. Rodriguésia 58:207-220.

MEYER, N., MitTERMEIER, R.A., MitTERMEIER, C.G., FONSECA, G. \& KENT, J. 2000. Biodiversity hotspots for conservation priorities. Nature 403:853-858.

MITTERMEIER, R.A.; GIL, P.R.; HOFFMANN, M.; PILGRIM, J.; BROOKS, T.; MITTERMEIER, C.G.; LAMOUREX, J. \& FONSECA, G.A.B. 2004. Hotspots revisited. Ed. CEMEX, Mexico City. Pp. 392.

MORAN, R.C. 2008. Diversity, biogeography, and floristics. In Biology and evolution of ferns and lycophytes (RANKER, T.A. \& HAUFLER, C.H., eds.). Ed. Cambridge University Press, Cambridge. Pp.367-394.

MYERS, N.; MITTERMEIER, R.A.; MITTERMEIER, C.G.; DA FONSECA, G.A. \& KENT, J. 2000. Biodiversity hotspots for conservation priorities. Nature 403:853858. 
NÓBREGA, G.A. \& PRADO, J. 2008. Pteridófitas da vegetação nativa do Jardim Botânico Municipal de Bauru, Estado de São Paulo, Brasil. Hoehnea 35:7-55.

PAGE, C.N. 1979. The diversity of ferns: an ecological perspective. In: DYER, A.F. (Ed.). The experimental biology of ferns. London: Academic Press, p. 10-56.

PPG I .2016. A community-derived classification for extant lycophytes and ferns. J. Syst. Evol. 54:563-603.

PREFEITURA DE JUIZ DE FORA 2017. Available at <http://www.pjf.mg.gov.br>. Access on 20 October 2017.

REZENDE, C.L.; SCARANO, F.R.; ASSAD, E.D.; JOLY, C.A.; METZGER, J.P.; STRASSBURG, B.B.N. \& MITTERMEIER, R.A. 2018. From hotspot to hopespot: An opportunity for the Brazilian Atlantic Forest. Persp. Ecol. Conser. 16:208-214.

RIBEIRO, M.C.; MARTENSEN, A.C; METZGER, J.P.; TABARELLI, M.; SCARANO, F.R. \& FORTIN, M.J. 2011. The Brazilian Atlantic Forest: a shrinking biodiversity hotspot. In Biodiversity Hotspots (ZACHOS, F.E., HABEL, J.C., eds). Ed. Springer, Berlin. Pp. 405-434.

RIBEIRO, M.C.; METZGER, J.P.; MARTENSEN, A.C.; PONZONI, F.J. \& HIROTA, M.M. 2009. The Brazilian Atlantic Forest: How much is left, and how is the remaining forest distributed? Implications for conservation. Biology Conservation 142:1141-1153.

SAlinO, A. \& ALMEIDA, T.E. 2009. Pteridófitas. In Plantas da Floresta Atlântica (STEHMANN, J.R.; FORZZA, R.C.; SALINO, A.; SOBRAL; M., COSTA, D.P. \& KAMINO, L.H.Y., eds.). Ed. Jardim Botânico do Rio de Janeiro, Rio de Janeiro. Pp.19-25.

SALINO, A.; MOTA, N.F.O. \& ALMEIDA, T.E. 2013. Lycophytes and monilophytes in Rio Preto State Park, Minas Gerais, Brazil. Acta Botanica Brasilica 27:252-263.

SCOLFORO, J.R.S. \& CARVALHO, L.M.T. 2006. Mapeamento e inventário da flora nativa e dos reflorestamentos de Minas Gerais. Ed. Universidade Federal de Lavras, Lavras. Pp 288.

SENNA, R.M. \& KAZMIRCZAK, C. 1997. Pteridófitas de um remanescente florestal no morro da extrema, Porto Alegre, RS. Revista FZVA 4:33-48.

SILVA, A.T. 1989. Pteridófitas. In Técnicas de coleta, preservação e herborização de 
material botânico (FIDALGO, O. \& BONONI, V.L.R., eds). Ed. Instituto de Botânica, São Paulo. Pp. 32-34.

SOUZA, F.S.; SALINO, A.; VIANA, P.L. \& SALIMENA, F.R.G. 2012. Ferns and lycophytes of Serra Negra, Minas Gerais, Brazil. Acta Botanica Brasilica 26:378390.

STEFFENS, C. \& WINDISCH, P.G. 2007. Diversidade e formas de vida de pteridófitas no Morro da Harmonia em Teutônia-RS, Brasil. Pesquisas, Botânica 58:375-382.

STEHMANN, J.R.; FORZZA, R.C.; SALINO, A.; SOBRAL, M.; COSTA, D.P. \& KAMINO, L.H.Y. 2009. Plantas da floresta Atlântica. Ed. Jardim Botânico do Rio de Janeiro, Rio de Janeiro.

THIERS, B. 2020. Index Herbariorum: A global directory of public herbaria and associated staff. New York Botanical Garden's Virtual Herbarium. Available at <http://sweetgum.nybg.org/ih/> Access on 03 March 2018.

TRYON, R.M. 1972. Endemic areas and speciation in tropical American ferns. Biotropica 4:76-84.

TRYON, R.M. 1986. The biogeography of species, with special reference to ferns. Botanical Review 52:118-156.

WHITMORE, T.C. 1978. Gaps in the forest canopy. In Tropical trees as living systems (TOM-LINSON, P.B. \& ZIMMERMAN, M.H., eds.). Cambridge University Press, London. Pp. 639-655.

ZUQUIM, G.; COSTA, F.R.C.; PRADO, J. \& TUOMISTO, H. 2008. Guia de samambaias e licófitas da REBIO Uatumã. Amazônia Central. Ed. Design, Manaus. Pp. 316. 
bioRxiv preprint doi: https://doi.org/10.1101/2021.02.17.431701; this version posted February 18, 2021. The copyright holder for this preprint (which was not certified by peer review) is the author/funder, who has granted bioRxiv a license to display the preprint in perpetuity. It is made available under aCC-BY-ND 4.0 International license. 
Figure 1. Number of samples of ferns and lycophytes in Juiz de Fora though the years.

Figure 2. Map showing the forest areas of Juiz de Fora.

Table 1. Ferns and lycophytes species in the municipality of Juiz de Fora. AE: anthropogenic environment, CO: Corticicolous, HC: Hemicorticicolous, MD: missing data, NC: not computed, RU: rupicolous, SSF: Seasonal Semideciduous Forest, TE: terricolous.

Taxon

\section{Anemiaceae}

Anemia collina Raddi

Anemia hirsuta (L.) Sw.

Anemia phyllitidis (L.) Sw.

Anemia raddiana Link

Anemia villosa Willd.

\section{Aspleniaceae}

Asplenium auriculatum Sw.

Asplenium auritum Sw.

Asplenium claussenii Hieron.

Asplenium formosum Willd.

Asplenium harpeodes Kunze

Asplenium inaequilaterale Willd.

Asplenium serratum L.

\section{Athyriaceae}

Deparia petersenii (Kunze) M. Kato

Diplazium cristatum (Desr.) Alston

Diplazium lindbergii (Mett.) Christ

Diplazium plantaginifolium (L.) Urb.

Blechnaceae

Blechnum austrobrasilianum de la Sota Blechnum gracile Kaulf.

\author{
Preferential \\ substrate \\ Environment Voucher
}

TE

RU/TE

NC

Krieger s.n (CESJ 11812)

TE

AE

Lima 17

Lima 02

Krieger

20151)

TE

SSF

SSF

Lima 29

TE

SSF

Krieger 10545

TE

SSF

Lima 143

TE

SSF

Dittrich 2185

TE

SSF

Krieger 9223

TE

SSF

Garcia 94

TE

SSF

Souza 232

TE

SSF

Krieger 17382

SSF

Lima 80

Damazio s.n. (CESJ 3348)

Krieger s.n. (CESJ 20748)

CESJ 2627

SSF

SSF

Lima 13

TE

SSF 


\begin{tabular}{|c|c|c|c|}
\hline Blechnum occidentale L. & $\mathrm{RU} / \mathrm{TE}$ & SSF/AE & $\begin{array}{l}\text { Novelino } \\
\text { 29977-B) }\end{array}$ s.n. (CESJ \\
\hline Blechnum polypodioides Raddi & TE & SSF & Lima 05 \\
\hline Lomaridium plumieri (Desv.) C.Presl & $\mathrm{RU} / \mathrm{HE}$ & SSF & Lima 57 \\
\hline $\begin{array}{l}\text { Neoblechnum brasiliense } \\
\text { Gasper \& V.A.O.Dittrich }\end{array}$ & TE & SSF & Lima 68 \\
\hline $\begin{array}{l}\text { Parablechnum cordatum (Desv.) Gasper } \\
\text { \& Salino }\end{array}$ & TE & SSF/AE & Novelino 1288 \\
\hline $\begin{array}{l}\text { Parablechnum proliferum (Rosenst.) } \\
\text { Gasper \& Salino }\end{array}$ & TE & & Krieger (CESJ2759) \\
\hline Salpichlaena volubilis (Kaulf.) J.Sm. & TE & SSF & Lima 58 \\
\hline $\begin{array}{l}\text { Telmatoblechnum serrulatum (Rich.) } \\
\text { Perrie, D.J.Ohlsen \& Brownsey }\end{array}$ & TE & SSF & \\
\hline \multicolumn{4}{|l|}{ Cyatheaceae } \\
\hline $\begin{array}{l}\text { Cyathea atrovirens (Langsd. \& Fisch.) } \\
\text { Domin }\end{array}$ & TE & SSF & Krieger (CESJ 20926) \\
\hline Cyathea corcovadensis (Raddi) Domin & TE & SSF & Lima 53 \\
\hline Cyathea delgadii Sternb. & TE & SSF & Lima 01 \\
\hline Cyathea leucofolis Domin & TE & SSF & Souza 411 \\
\hline Cyathea mexiae Copel. & TE & SSF & Lima 54 \\
\hline Cyathea phalerata Mart. & TE & SSF & Lima 60 \\
\hline $\begin{array}{lll}\text { Sphaeropteris } & \text { gardneri } & \text { (Hook.) } \\
\text { R.M.Tryon } & & \end{array}$ & TE & SSF & Krieger 10719 \\
\hline \multicolumn{4}{|l|}{ Dennstaedtiaceae } \\
\hline Dennstaedtia globulifera (Poir.) Hieron. & TE & SSF & Souza 387 \\
\hline Hypolepis mitis Kunze ex Kuhn & TE & SSF & Lima 41 \\
\hline Pteridium arachnoideum (Kaulf.) Maxon & TE & $\mathrm{AE}$ & $\begin{array}{l}\text { Novelino } \\
\text { 29969) }\end{array}$ \\
\hline
\end{tabular}

\section{Didymochlaenaceae}

Didymochlaena truncatula (Sw.) J.Sm. TE

SSF

Krieger (CESJ 7035)

\section{Dryopteridaceae}

Ctenitis aspidioides (C.Presl) Copel. TE

SSF

Garcia 85

Ctenitis christensenii R.S.Viveros \& TE

Salino

SSF

Brade 15812

Ctenitis deflexa (Kaulf.) Copel.

TE

SSF

Brade 15909

Ctenitis distans (Brack.) Ching var. TE distans

SSF

Lima 42

Ctenitis submarginalis (Langsd. \& TE

Fisch.) Ching var. submarginalis

SSF

Krieger

17108)

Ctenitis submarginalis var. tenuifolia TE

SSF

Lima 104 
(C.Presl) R.S. Viveros \& Salino

\begin{tabular}{|c|c|c|c|c|c|c|}
\hline $\begin{array}{l}\text { Elaphoglossum acrocarpum } \\
\text { T.Moore }\end{array}$ & (Mart.) & $\mathrm{CO}$ & SSF & $\begin{array}{l}\text { Krieger } \\
10541)\end{array}$ & s.n. & (CESJ \\
\hline $\begin{array}{l}\text { Elaphoglossum macrophyllum (N } \\
\text { Kuhn) Christ }\end{array}$ & Mett. ex & $\mathrm{CO}$ & SSF & $\begin{array}{l}\text { Krieger } \\
10541)\end{array}$ & s.n. & (CESJ \\
\hline $\begin{array}{l}\text { Elaphoglossum nigrescens } \\
\text { T.Moore ex Diels }\end{array}$ & (Hook.) & $\mathrm{CO}$ & SSF & RB 6823 & & \\
\hline $\begin{array}{l}\text { Megalastrum umbrinum } \\
\text { A.R.Sm. \& R.C.Moran }\end{array}$ & (C.Chr.) & TE & SSF & $\begin{array}{l}\text { Schwacke } \\
3428)\end{array}$ & s.n. & (CESJ \\
\hline $\begin{array}{l}\text { Mickelia scandens (Raddi) R.C. } \\
\text { Labiak \& Sundue }\end{array}$ & Moran, & TE & SSF & Dittrich 21 & & \\
\hline Parapolystichum effusum (Sw.) C & Ching & TE & SSF & $\begin{array}{l}\text { Krieger } \\
11789)\end{array}$ & s.n. & (CESJ \\
\hline Polybotrya pilosa Brade & & $\mathrm{HC}$ & SSF & Lima 46 & & \\
\hline Polybotrya speciosa Schott & & $\mathrm{HC}$ & SSF & Novelino 4 & 12 & \\
\hline Rumohra adiantiformis (G. Forst.) & .) Ching & TE & SSF & $\begin{array}{l}\text { Krieger } \\
63519)\end{array}$ & s.n. & (CESJ \\
\hline Stigmatopteris bradei Rosenst. & & TE & SSF & Brade 159 & 14 & \\
\hline $\begin{array}{l}\text { Stigmatopteris } \\
\text { R.C.Moran }\end{array}$ & (Fée) & TE & SSF & $\begin{array}{l}\text { Krieger } \\
93100)\end{array}$ & s.n. & (BHCB \\
\hline Stigmatopteris prionites (Kunze) & C.Chr. & TE & SSF & $\begin{array}{l}\text { Krieger } \\
17107)\end{array}$ & s.n. & (CESJ \\
\hline
\end{tabular}

\section{Equisetaceae}

Equisetum giganteum L. $\quad$ TE

MD

Krieger s.n. (CESJ 1296)

\section{Gleicheniaceae}

\begin{tabular}{|c|c|c|c|}
\hline $\begin{array}{l}\text { Dicranopteris flexuosa } \\
\text { Underw. }\end{array}$ & TE & SSF & Lima 34 \\
\hline Gleichenella pectinata (Willd.) Ching & TE & SSF & Lima 45 \\
\hline Sticherus bifidus (Willd.) Ching & TE & SSF & Lima 94 \\
\hline Sticherus gracilis (Mart.) Copel. & TE & SSF & Lima 216 \\
\hline Sticherus lanuginosus (Fée) Nakai & TE & SSF & Lima 06 \\
\hline $\begin{array}{l}\text { Sticherus nigropaleaceus (J.W.Sturm) } \\
\text { J.Prado \& Lellinger }\end{array}$ & TE & SSF & Lima 20 \\
\hline \multicolumn{4}{|l|}{ Hymenophyllaceae } \\
\hline $\begin{array}{l}\text { Didymoglossum krausii (Hook \& Grev.) } \\
\text { C. Presl }\end{array}$ & TE & SSF & s.n. (CESJ \\
\hline Didymoglossum reptans (Sw.) C. Presl & $\mathrm{CO}$ & SSF & Roth s.n. (BHCB 51794) \\
\hline Hymenophyllum polyanthos (Sw.) Sw. & $\mathrm{CO}$ & SSF & Krieger s.n. (BHCB 4255) \\
\hline $\begin{array}{l}\text { Polyphlebium angustatum (Carmich.) } \\
\text { Ebihara \& Dubuisson }\end{array}$ & $\mathrm{CO}$ & SSF & Almeida 29 \\
\hline
\end{tabular}




\begin{tabular}{|c|c|c|c|}
\hline Trichomanes elegans Rich. & TE & SSF & Leoni 2910 \\
\hline Trichomanes pinnatum Hedw. & TE & SSF & Leoni 2968 \\
\hline Trichomanes polypodioides Raddi & TE & SSF & $\begin{array}{l}\text { Krieger } \\
21291)\end{array} \quad$ s.n. (CES \\
\hline Vandenboschia radicans (Sw.) Copel. & $\mathrm{CO}$ & SSF & Krieger s.n. (BHCB 4334) \\
\hline \multicolumn{4}{|l|}{ Lindsaeaceae } \\
\hline $\begin{array}{l}\text { Lindsaea quadrangularis Raddi subsp. } \\
\text { quadrangularis }\end{array}$ & TE & SSF & Brade s.n. (CESJ 3438) \\
\hline Lindsaea stricta (Sw.) Dryand. & $\mathrm{TE}$ & SSF & Lima 128 \\
\hline \multicolumn{4}{|l|}{ Lomariopsidaceae } \\
\hline Lomariopsis marginata (Schrad.) Kuhn & $\mathrm{HC}$ & SSF & Souza 235 \\
\hline \multicolumn{4}{|l|}{ Nephrolepidaceae } \\
\hline Nephrolepis biserrata (Sw.) Schott & TE & SSF & Krieger (CESJ 18822) \\
\hline Nephrolepis exaltata (L.) Schott & TE & SSF & Lima 139 \\
\hline Nephrolepis pectinata (Willd.) Schott & $\mathrm{CO}$ & $\mathrm{AE}$ & Furtado 83 \\
\hline \multicolumn{4}{|l|}{ Lycopodiaceae } \\
\hline $\begin{array}{l}\text { Palhinhaea camporum B.Øllg. \& } \\
\text { P.G.Windisch }\end{array}$ & TE & SSF & Santos s.n. (CESJ 30071) \\
\hline Palhinhaea cernua (L.) Franco \& Vasc. & TE & SSF & Lima 04 \\
\hline $\begin{array}{l}\text { Phlegmariurus mandiocanus (Raddi) } \\
\text { B.Øllg. }\end{array}$ & TE & SSF & Krieger s.n. (CESJ 2774) \\
\hline Phlegmariurus reflexus (Lam.) B.Øllg. & TE & $\mathrm{AE}$ & Lima 08 \\
\hline $\begin{array}{l}\text { Lycopodiella geometra B.Øllg. \& } \\
\text { P.G.Windisch }\end{array}$ & $\mathrm{TE}$ & SSF & Santos s.n. (CESJ 30069) \\
\hline Lycopodium clavatum L. & TE & $\mathrm{AE}$ & Lima 92 \\
\hline $\begin{array}{l}\text { Pseudolycopodiella caroliniana (L.) } \\
\text { Holub }\end{array}$ & TE/RU & $\mathrm{AE}$ & Lima 37 \\
\hline
\end{tabular}

\section{Lygodiaceae}

Lygodium volubile Sw.

TE

SSF

Lima 129

\section{Marattiaceae}

Danaea excurrens Rosenst.

TE

SSF

Garcia 92

Ophioglossaceae

Ophioglossum reticulatum L.

TE

AE

Scalon 452

\section{Osmundaceae}

Osmunda regalis L.

TE

BR

Lima 69

\section{Polypodiaceae}

Campyloneurum crispum Fée 
C.Presl

Campyloneurum nitidum (Kaulf.) C.Presl TE

Campyloneurum rigidum J.Sm.

CO/RU

Moranopteris achilleifolia (Kaulf.) R.Y.Hirai \& J.Prado

$\mathrm{CO}$

Microgramma crispata (Fée) R.M. Tryon \& A.F.Tryon

$\mathrm{CO}$

Microgramma geminata (Schrad.) Mickel CO

Microgramma lindbergii (Mett.) de la CO Sota

Microgramma percussa (Cav.) de la CO Sota

Microgramma squamulosa (Kaulf.) de la CO Sota

Microgramma tecta (Kaulf.) Alston

$\mathrm{CO}$

Microgramma vacciniifolia (Langsd. \& CO Fisch.) Copel.

Niphidium crassifolium (L.) Lellinger TE

Pecluma plumula (Humb. \& Bonpl. ex Willd.) M.G.Price

CO

Pecluma robusta (Fée) M.Kessler \& A.R.Sm.

$\mathrm{CO} / \mathrm{TE}$

Lellinger

Pleopeltis astrolepis (Liebm.) E.Fourn. $\quad \mathrm{CO}$

Pleopeltis hirsutissima (Raddi) de la CO Sota

Pleopeltis macrocarpa (Bory ex Willd.) CO Kaulf.

Pleopeltis minima (Bory) J.Prado \& CO R.Y.Hirai

Pleopeltis pleopeltifolia (Raddi) Alston CO

Serpocaulon catharinae (Langsd. \& CO Fisch.) A.R.Sm

Serpocaulon latipes (Langsd. \& Fisch.) CO A.R.Sm.

Serpocaulon meniscifolium (Langsd. \& CO Fisch.) A.R.Sm.

Serpocaulon polystichum (Link) A.R.Sm. CO

Serpocaulon triseriale (Sw.) A.R.Sm. CO
SSF

SSF

SSF

SSF

SSF

SSF

SSF

$\mathrm{AE}$

$\mathrm{AE}$

SSF

SSF

SSF

SSF

$\mathrm{AE}$

Krieger 199

Mota 42

Krieger s.n. (BHCB 4382)

Lima 126

Krieger s.n. (UEC 63111)

Krieger s.n. (BHCB 166028)

Krieger s.n. (CESJ 2678)

Lima 113

Lima 142

Neto 1147

Krieger s.n. (CESJ 2784)

Krieger s.n. (CESJ 20440)

Lima 44

Lima 108

Lima 83

Lima 81

SSF

Krieger s.n. (CESJ 2789)

$\mathrm{AE}$

Krieger s.n. (CESJ 2692)

AE

Lima 102

SSF

Lima 43

AE

Krieger s.n. (CESJ 11933)

SSF

CESJ 1164

SSF

Lima 50

AE

Lima 114

\section{Pteridaceae}




\begin{tabular}{|c|c|c|c|}
\hline Adiantopsis chlorophylla (Sw.) Fée & TE & $\mathrm{AE}$ & Lima 76 \\
\hline Adiantopsis radiata (L.) Fée & TE & SSF & Lima 87 \\
\hline Adiantum dolosum Kunze & TE & SSF & Souza 341 \\
\hline Adiantum glaucescens Klotzsch & TE & $\mathrm{AE}$ & Lima 127 \\
\hline Adiantum latifolium Lam. & TE & SSF & $\begin{array}{l}\text { Krieger 20435, Krieger } \\
\text { s.n. (CESJ 2729) }\end{array}$ \\
\hline Adiantum obliquum Willd. & TE & SSF & $\begin{array}{l}\text { Viana s.n. (BHCB } \\
\text { 109111), Souza et al. } 468 \\
\text { (CESJ) }\end{array}$ \\
\hline Adiantum ornithopodum C.Presl ex Kuhn & TE & SSF & Brade 15915 \\
\hline $\begin{array}{l}\text { Adiantum pentadactylon Langsd. \& } \\
\text { Fisch. }\end{array}$ & TE & SSF & Lima 16 \\
\hline Adiantum pulverulentum $\mathrm{L}$. & TE & SSF & Krieger 1172 \\
\hline Adiantum raddianum C. Presl & TE & $\mathrm{AE}$ & Lima 15 \\
\hline Adiantum subcordatum Sw. & TE & SSF & Lima 127 \\
\hline $\begin{array}{l}\text { Doryopteris concolor (Langsd. \& Fisch.) } \\
\text { Kuhn }\end{array}$ & TE & SSF & Lima 86 \\
\hline Doryopteris collina (Raddi) J.Sm. & TE & SSF & s.n. (CESJ \\
\hline Doryopteris nobilis (T.Moore) C.Chr. & $\mathrm{RU} / \mathrm{TE}$ & SSF & Lima 22 \\
\hline Doryopteris patula Fée & RU & SSF & Souza et al. 460 (CESJ) \\
\hline Doryopteris pedata (L.) Fée & TE & SSF & Câmara s.n. (CESJ 9225) \\
\hline Doryopteris pentagona Pic.Serm. & TE & SSF & Lima 85 \\
\hline Doryopteris varians (Raddi) J.Sm. & TE & SSF & Krieger s.n. (BHCB 4269) \\
\hline Hemionitis tomentosa (Lam.) Raddi & TE & SSF & Lima 75 \\
\hline Lytoneuron crenulans (Fée) Yesilyurt & TE & SSF & Krieger s.n. (CESJ 8397) \\
\hline $\begin{array}{l}\text { Lytoneuron lomariaceum } \quad \text { (Klotzsch) } \\
\text { Yesilyurt }\end{array}$ & TE & $\mathrm{AE}$ & $\begin{array}{l}\text { Novelino s.n. (CESJ } \\
\text { 21088) }\end{array}$ \\
\hline $\begin{array}{l}\text { Lytoneuron ornithopus (Hook. \& Baker) } \\
\text { Yesilyurt }\end{array}$ & TE & SSF & Roth s.n. (CESJ 192) \\
\hline Pityrogramma calomelanos (L.) Link & TE & $\mathrm{AE}$ & Lima 11 \\
\hline Pteris brasiliensis Raddi & TE & SSF & Lima 89 \\
\hline Pteris decurrens C.Presl & TE & SSF & Castro 160 \\
\hline Pteris denticulata Sw. & TE & $\mathrm{AE}$ & Lima 74 \\
\hline Pteris leptophylla Sw. & TE & SSF & $\begin{array}{l}\text { Krieger } \\
17106)\end{array}$ \\
\hline Pteris quadriaurita Retz. & TE & SSF & $\begin{array}{l}\text { Krieger } \\
25556)\end{array}$ \\
\hline Pteris splendens Kaulf. & TE & SSF & $\begin{array}{l}\text { Lima 88, Souza et al. } 239 \\
\text { (CESJ) }\end{array}$ \\
\hline
\end{tabular}


Pteris vittata L.
Tryonia myriophylla (Sw.) Schuettp., J. Prado \& A.T.Cochran

Saccolomataceae

Saccoloma elegans Kaulf.

TE

Salviniaceae

Salvinia biloba Raddi

$A Q$

Selaginellaceae

Selaginella convoluta (Arn.) Spring

MD

Selaginella decomposita Spring

Selaginella muscosa Spring

Selaginella suavis (Spring) Spring

Selaginella sulcata (Desv. ex Poir.)

Spring ex Mart.

Selaginella tenuissima Fée

Tectariaceae

Tectaria pilosa (Fée) R.C.Moran

TE

Tectaria poeppigii (C. Presl) C. Chr.

TE

Thelypteridaceae

Amauropelta amambayensis (Christ) Salino \& A.R.Sm. Amauropelta neglecta (Brade \& TE
Rosenst.) Salino \& T.E.Almeida

Amauropelta oligocarpa (Humb. \& TE Bonpl. ex Willd.) Ching

Amauropelta opposita (M.Vahl) TE

Pic.Serm.

Amauropelta ptarmica (Mett.) Pic.Serm. TE

Amauropelta regnelliana (C.Chr.) Salino

\& T.E.Almeida

TE

Amauropelta rivularioides (Fée) Salino \&

T.E.Almeida

$T E$

Christella dentata (Forssk.) Brownsey \& TE Jermy

Christella conspersa (Schrad.) A.R.Sm. TE

Christella hispidula (Decne.) C.F.Reed TE

Cyclosorus interruptus (Willd.) K.Iwats.

Goniopteris vivipara (Raddi) Brade

SSF

Krieger s.n. (CESJ 65997)

SSF

Krieger s.n. (CESJ17104)

SSF

Lima 10

SSF

SSF

SSF

SSF

Krieger s.n. (CESJ 10759)

Krieger s.n. (CESJ 10721)

Lima 07

Garcia s.n. (CESJ 26063)

SSF

Lima 19

SSF

Lima 24

AE

Lima 12

MD

Roth s.n. (CESJ 1292)

Krieger 43990)

SSF

Lima 146

SSF

Krieger 1175 


\begin{tabular}{|c|c|c|c|c|c|}
\hline $\begin{array}{l}\text { Macrothelypteris torresiana (Gaudich.) } \\
\text { Ching }\end{array}$ & TE & $\mathrm{AE}$ & $\begin{array}{l}\text { Novelino } \\
29987)\end{array}$ & s.n. & (CESJ \\
\hline $\begin{array}{l}\text { Meniscium arborescens Humb. \& Bonpl. } \\
\text { ex Willd. }\end{array}$ & TE & SSF & Lima 99 & & \\
\hline Meniscium longifolium Desv. & TE & SSF & $\begin{array}{l}\text { Krieger } \\
24530)\end{array}$ & s.n. & (CESJ \\
\hline Meniscium serratum Cav. & TE & SSF & Lima 14 & & \\
\hline $\begin{array}{l}\text { Steiropteris decussata (L.) A.R.Sm. var. } \\
\text { brasiliensis (C.Chr.) Salino \& T.E. } \\
\text { Almeida }\end{array}$ & TE & SSF & \multicolumn{3}{|c|}{ Krieger s.n. (CESJ 3585) } \\
\hline $\begin{array}{l}\text { Steiropteris hatschbachii (A.R.Sm.) } \\
\text { Salino \& T.E.Almeida }\end{array}$ & TE & SSF & \multicolumn{3}{|c|}{ Souza 371} \\
\hline Steiropteris leprieurii (Hook.) R.M.Tryon & TE & SSF & \multicolumn{3}{|c|}{ Belchior 23} \\
\hline $\begin{array}{l}\text { Steiropteris mexiae (C.Chr. ex Copel.) } \\
\text { Salino \& T.E.Almeida }\end{array}$ & TE & SSF & \multicolumn{3}{|l|}{ Lima 51} \\
\hline
\end{tabular}


Table 2. Comparison among studies that inventoried the Seasonal Semideciduous Forest (SSF) areas in the Atlantic Forest.

\begin{tabular}{|c|c|c|c|c|c|}
\hline Reference & Locality & $\begin{array}{l}\text { Vegetation } \\
\text { formations }\end{array}$ & $\begin{array}{c}\text { Area } \\
\text { (ha) }\end{array}$ & $\begin{array}{l}\text { Elevation } \\
\quad(\mathrm{m})\end{array}$ & $\begin{array}{l}\text { Total of } \\
\text { spp. }\end{array}$ \\
\hline Present study & Juiz de Fora & SSF & 142988 & $467-1104$ & 181 \\
\hline Salino et al. 2013 & $\begin{array}{l}\text { Parque Estadual do } \\
\text { Rio Preto }\end{array}$ & $\begin{array}{l}\text { SSF and } \\
\text { Cerrado }\end{array}$ & 12000 & $750-1850$ & 185 \\
\hline Colli et al. 2007 & $\begin{array}{c}\text { Reserva Estadual de } \\
\text { Águas da Prata }\end{array}$ & $\begin{array}{l}\text { Riparian Forest } \\
\text { and SSF }\end{array}$ & 48,40 & $840-1060$ & 39 \\
\hline Colli et al. 2004a & $\begin{array}{l}\text { Floresta Estadual de } \\
\text { Bebedouro }\end{array}$ & $\begin{array}{l}\text { Riparian Forest, } \\
\text { Cerrado, and } \\
\text { SSF }\end{array}$ & 99,5 & 570 & 10 \\
\hline Colli et al. 2004b & $\begin{array}{c}\text { Parque Estadual da } \\
\text { Vassununga }\end{array}$ & SSF & 1732 & $500-750$ & 34 \\
\hline Souza et al. 2012 & Serra Negra & $\begin{array}{l}\text { Rain Forest, } \\
\text { Highland Fields, } \\
\text { and SSF }\end{array}$ & 10000 & $900-1698$ & 209 \\
\hline $\begin{array}{l}\text { Figueiredo \& Salino } \\
\qquad 2005\end{array}$ & $\begin{array}{l}\text { Patrimônio Natural } \\
\text { ao Sul da } \\
\text { Região } \\
\text { Metropolitana de } \\
\text { Belo Horizonte }\end{array}$ & $\begin{array}{c}\text { Cerrado, } \\
\text { Ferruginous } \\
\text { Fields, and SSF }\end{array}$ & 2280 & $850-1420$ & 190 \\
\hline Melo \& Salino 2002 & $\begin{array}{l}\text { Estação Biológica de } \\
\text { Caratinga }\end{array}$ & SSF & 880 & $400-680$ & 102 \\
\hline Melo \& Salino 2002 & $\begin{array}{l}\text { Parque Estadual do } \\
\text { Rio Doce }\end{array}$ & SSF & 35970 & $230-515$ & 116 \\
\hline Melo \& Salino 2007 & APA Fernão Dias & $\begin{array}{l}\text { Rain Forest and } \\
\text { SSF }\end{array}$ & 180 & $\begin{array}{l}1000- \\
2068\end{array}$ & 173 \\
\hline $\begin{array}{c}\text { Nobrega \& Prado } \\
2008\end{array}$ & $\begin{array}{c}\text { Jardim Botânico } \\
\text { Municipal de } \\
\text { Bauru }\end{array}$ & $\begin{array}{l}\text { Cerrado, } \\
\text { Riparian Forest, } \\
\text { and SSF }\end{array}$ & 321,71 & $510-540$ & 54 \\
\hline $\begin{array}{c}\text { Senna \& Kazmirczak } \\
1997\end{array}$ & $\begin{array}{l}\text { Morro da } \\
\text { Extrema. Porto } \\
\text { Alegre }\end{array}$ & SSF & 1031 & Up to 255 & 45 \\
\hline
\end{tabular}




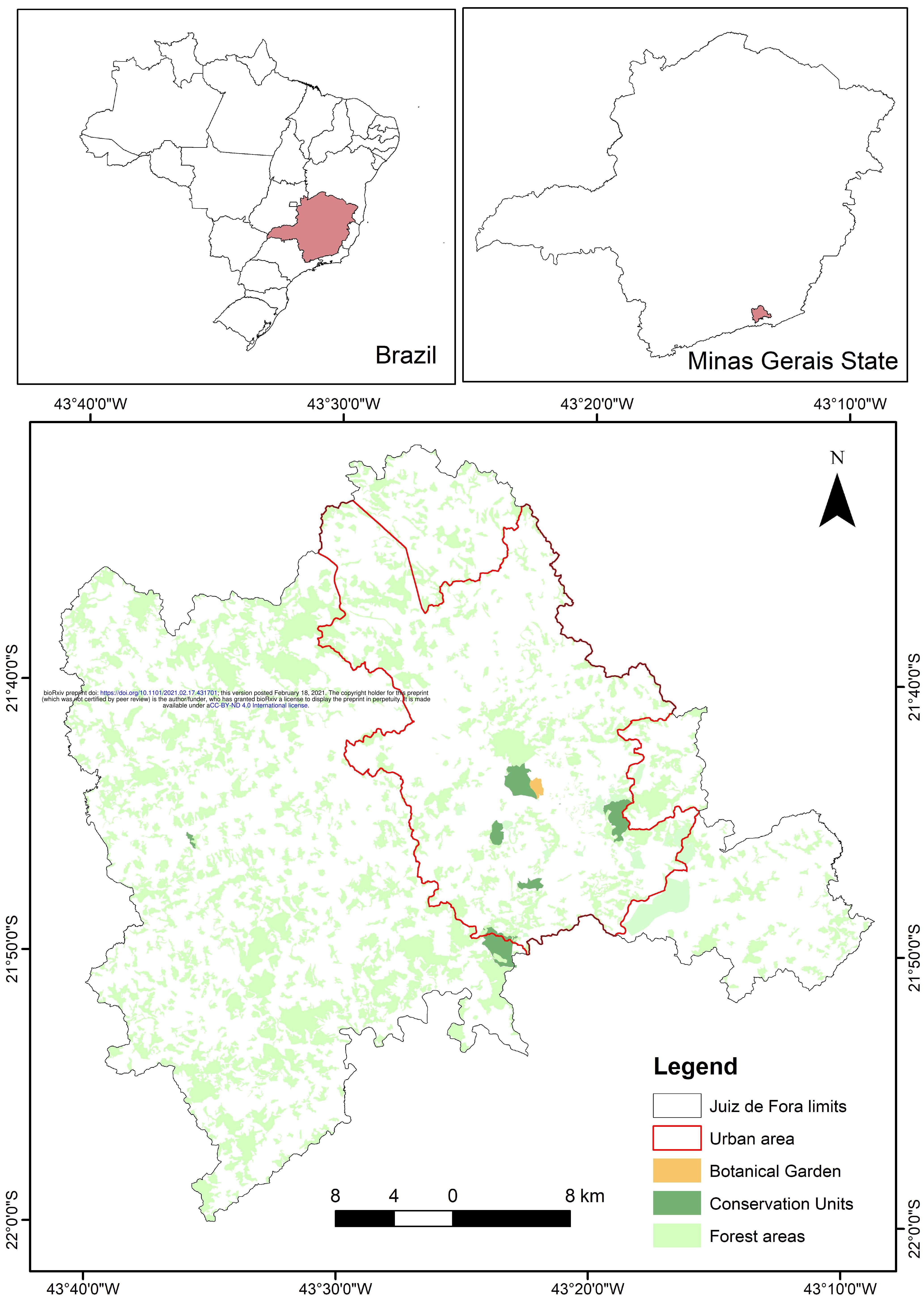

